\title{
VCAN Gene
}

National Cancer Institute

\section{Source}

National Cancer Institute. VCAN Gene. NCI Thesaurus. Code C113261.

This gene is involved in both cell adhesion and proteoglycan metabolism. 